\title{
Heat-Resistant Bacterial Phytase in Broiler Pelleted Diets
}

http://dx.doi.org/10.1590/1516-635x170145-48

\section{-Author(s) \\ Carlos TC de $\mathrm{F}^{\prime}$ \\ Barbosa LCGS' \\ Shiroma NN" \\ Dari RL" \\ Baolin G"I \\ Yongcheng $\mathrm{W}^{\mathrm{II}}$ \\ Araújo CS da S \\ Araújo LF}

Departamento de Nutrição e Produção Animal, FMVZ/USP - Campus Pirassununga. teresa_cristina_c@hotmail.com

"Salus Comércio de Produtos de Saúde e Nutrição Animal Ltda.

III Beijing Smile Feed Sci \& Tech Co., Ltd.

Abstract published in the proceedings of the 2nd Congress on Additives in Animal Feed - CBNA/2012, Brazil

\section{Mail Address}

Corresponding author e-mail address Carlos TC de F

Departamento de Nutrição e Produção Animal, FMVZ/USP - Campus

Pirassununga

E-mail: teresa_cristina_c@hotmail.com

\section{nKeywords}

Performance, digestibility, enzyme, phytate, phosphorus, broiler nutrition.

\section{ABSTRACT}

The objective of the study was to evaluate the effects of a heatresistant bacterial phytase added to pelleted diets on mineral digestibility, live performance, carcass traits, and bone quality of broilers. Three treatments were evaluated: Positive control; negative control, with 0.10 points reduction in calcium level and 0.15 points reduction in available phosphorus level; and negative control + phytase at 500 FTU/ $\mathrm{kg}$. Mineral digestibility and bone quality results demonstrated that the evaluated phytase resisted pelleting as it increased the utilization of the minerals present in the diet.

\section{INTRODUCTION}

Enzymes are protein that play specific roles in biochemical reaction, and are macromolecules known for their extraordinary specificity and catalytic power. Among exogenous enzymes studied and utilized in monogastric diets, phytase is applied to increase the availability of nutrient present in complexes with the phytate molecule of plant feedstuffs (Dari, 2004). Moreover, phytase reduces the environmental impact caused by excessive phosphorus excretion (Bess et al., 2006), contributing for the sustainability of poultry production.

The objective of the study was to evaluate the effects of a heatresistant bacterial phytase added to pelleted diets on mineral digestibility, live performance, carcass traits, and bone quality of broilers.

\section{MATERIAL AND METHODS}

The experiment was carried out at the Center of Poultry Research of the School of Veterinary Medicine and Animal Science of Universidade de São Paulo, Pirassununga campus, Brazil. Two trials were performed: one to evaluate mineral digestibility and the other to evaluate broiler performance, carcass traits, and bone quality.

Mineral digestibility was evaluated using 240 one-d-old Cobb 500 broilers distributed according to a completely randomized experimental design consisting of three treatments (positive control; negative control, with 0.10 points reduction in calcium level and 0.15 points reduction in available phosphorus level; and negative control + phytase at 500 FTU/kg), with eight replicates of 10 birds each. Birds were housed in metabolic cages and reared from one to 21 days old.

The experimental diets were formulated to supply the nutritional requirements recommended by Rostagno et al. (2011) for the starter phase (1-21 days) and are presented in Table 1. The phytase product derived from the expression of the $\mathrm{E}$. coli gene changed by mutagenesis to make the molecule resistant to pelleting temperature. The positive control feed was supplied to all birds until they were 13 days old. On 
day 14 , the experimental diets started to be fed until day 21 , with five days of adaptation and three days of total excreta collection.

At the end of the trial, the feces collected per replicate were homogenized, and a sample was remover, weighed, and pre-dried in a forced-ventilation oven at $65^{\circ} \mathrm{C}$ for $72 \mathrm{~h}$. Samples were exposed to air until they reached environment temperature and humidity. Samples were then weighed, ground, properly packed, and submitted to the laboratory for calcium and phosphorus analyses, together with the experimental diets. Data were analyzed using the GLM procedure of SAS (2001) statistical package and means were compared by the test of Tukey at $5 \%$ significance level.

Live performance, carcass traits, and bone quality were evaluated using 350 one-d-old Cobb 500 broilers distributed according to a completely randomized experimental design consisting of three treatments (positive control; negative control, with 0.10 points reduction in calcium level and 0.15 points reduction in available phosphorus level; and negative control + phytase at $500 \mathrm{FTU} / \mathrm{kg}$ ), with eight replicates of 15 birds each. Birds were housed in 24 floor pens and reared from one to 42 days old.

The experimental diets were formulated to supply the nutritional requirements recommended by Rostagno et al. (2011). Three feeding phases were applied: starter (1-21 days), grower (21-33 days), and finisher (33-42 days), and are presented in Table 1. The phytase product derived from the expression of the $\mathrm{E}$. coli gene changed by mutagenesis to make the molecule resistant to pelleting temperature.

Birds and feeds were weighed on days 1, 21, and 42 to determine feed intake, weight gain, and feed conversion ratio. At the end of the experiment, when broilers were 42 days old, two birds per replicate were sacrificed to determine carcass, breast, and leg yields. The right tibiae were collected for the analyses of calcium, phosphorus, and ash contents. Data were analyzed using the GLM procedure of SAS (2001) statistical package and means were compared by the test of Tukey at $5 \%$ significance level.

Table 1 - Ingredients and nutritional composition of the experimental diets.

\begin{tabular}{|c|c|c|c|c|c|c|}
\hline \multirow[t]{2}{*}{ Ingredients, kg } & \multicolumn{2}{|c|}{ Starter } & \multicolumn{2}{|c|}{ Grower } & \multicolumn{2}{|c|}{ Finisher } \\
\hline & $P C^{*}$ & $N C^{* *}$ & PC & NC & PC & NC \\
\hline Corn & 58.20 & 58.97 & 62.55 & 63.33 & 66.82 & 67.60 \\
\hline Soybean meal & 35.58 & 35.35 & 30.55 & 30.32 & 26.60 & 26.43 \\
\hline Dicalcium phosphate & 1.76 & 0.95 & 1.31 & 0.49 & 1.11 & 0.30 \\
\hline Soybean oil & 2.00 & 2.00 & 3.26 & 3.26 & 3.19 & 3.19 \\
\hline Calcitic limestone & 0.81 & 1.08 & 0.83 & 1.10 & 0.73 & 0.99 \\
\hline Salt & 0.45 & 0.45 & 0.40 & 0.40 & 0.40 & 0.40 \\
\hline Mineral and vitamin supplement ${ }^{1}$ & 0.40 & 0.40 & 0.40 & 0.40 & 0.40 & 0.40 \\
\hline DL-methionine & 0.34 & 0.34 & 0.29 & 0.29 & 0.26 & 0.26 \\
\hline L-lysine & 0.33 & 0.33 & 0.30 & 0.30 & 0.32 & 0.32 \\
\hline L-threonine & 0.12 & 0.12 & 0.10 & 0.10 & 0.10 & 0.10 \\
\hline Total & 100.00 & 100.00 & 100.00 & 100.00 & 100.00 & 100.00 \\
\hline \multicolumn{7}{|l|}{ Calculated nutritional composition } \\
\hline Metabolizable energy, kcal/kg & 3,005 & 3,005 & 3,150 & 3,150 & 3,200 & 3,200 \\
\hline Crude protein, \% & 21.80 & 21.80 & 19.80 & 19.80 & 18.40 & 18.40 \\
\hline Calcium, \% & 0.88 & 0.78 & 0.76 & 0.66 & 0.66 & 0.56 \\
\hline Available phosphorus, \% & 0.44 & 0.29 & 0.35 & 0.20 & 0.31 & 0.16 \\
\hline Sodium, \% & 0.22 & 0.22 & 0.20 & 0.20 & 0.20 & 0.20 \\
\hline Sulfur amino acids, $\%$ & 0.92 & 0.92 & 0.83 & 0.83 & 0.77 & 0.77 \\
\hline Digestible lysine, \% & 1.27 & 1.27 & 1.13 & 1.13 & 1.06 & 1.06 \\
\hline Digestible threonine, \% & 0.83 & 0.83 & 0.74 & 0.74 & 0.69 & 0.69 \\
\hline Digestible valine, \% & 0.88 & 0.88 & 0.80 & 0.80 & 0.74 & 0.74 \\
\hline
\end{tabular}




\section{RESULTS AND DISCUSSION}

The results presented in Table 2 show that the applied treatments did not influence ash or calcium excretion ( $p>0.05)$. However, when diets with phosphorus reduction were fed, excreta phosphorus content was also reduced when compared with the broilers fed the positive-control diet $(p<0.05)$.

Table 2 - Excretion of nutrients in broilers fed the experimental diets.

\begin{tabular}{|c|c|c|c|c|c|c|}
\hline & \multicolumn{3}{|c|}{ Treatments* } & \multirow{2}{*}{$\frac{C V}{\%}$} & \multirow[t]{2}{*}{ SEM } & \multirow[t]{2}{*}{ P } \\
\hline & $P C$ & $\mathrm{NC}$ & $\begin{array}{c}\mathrm{NC}+ \\
\text { phytase }\end{array}$ & & & \\
\hline $\begin{array}{l}\text { Ashes } \\
\text { (g/bird/d) }\end{array}$ & 4.0 & 3.6 & 3.3 & 13.51 & 0.7 & 0.094 \\
\hline $\begin{array}{l}\text { Calcium } \\
\text { (mg/bird/d) }\end{array}$ & 428 & 428 & 405 & 18.04 & 73 & 0.202 \\
\hline $\begin{array}{l}\text { Phosphorus } \\
\text { (mg/bird/d) }\end{array}$ & $321^{b}$ & $250^{a}$ & $232^{a}$ & 11.15 & 34 & 0.012 \\
\hline
\end{tabular}

* PC - positive control; NC - negative control. $(p<0.05)$

The dietary addition of phytase promoted higher calcium and phosphorus retention relative to positive and negative control diet, as shown in Table 3.Ash retention was numerically different among treatments, with broilers fed the diet with phytase presenting higher retention, despite the lack of statistical difference ( $p>0.05)$.

These results are consistent with those reported by Dourado et al. (2006), who evaluated the effect of phytase supplementation to broiler diets on nutrient digestibility and found higher phosphorus retention in birds fed diets with phytase supplementation.

Table 3 - Retention of nutrients in broilers fed the experimental diets.

\begin{tabular}{|c|c|c|c|c|c|c|}
\hline & \multicolumn{3}{|c|}{ Treatments* } & $C V$ & SEM & $P$ \\
\hline & PC & NC & $\mathrm{NC}+$ phytase & $\%$ & & \\
\hline Ashes, \% & 31.13 & 26.63 & 34.38 & 7.63 & 2.28 & 0.166 \\
\hline Calcium, \% & $50.00^{b}$ & $45.63^{c}$ & $55.14^{a}$ & 4.99 & 4.02 & 0.037 \\
\hline Phosphorus, \% & $54.38^{b}$ & $52.00^{\mathrm{b}}$ & $59.29^{a}$ & 5.17 & 2.92 & 0.006 \\
\hline
\end{tabular}

* PC - positive control; NC - negative control. $(p<0.05)$

This is in agreement with the findings of Fukayama et al. (2008) from a study on the effect of phytase supplementation on nutrient digestibility in broilers that calcium digestibility was not different during the phase of one to 21 days between birds fed reduced nutritional levels and supplemented with phytase and those fed the positive control diet. Broilers fed the diets with reduced nutritional levels presented lower phosphorus digestibility than those fed the positive control diet; however, the supplementation of phytase to the negative control diet improved phosphorus digestibility.

When evaluating the effect of the dietary supplementation of phytase on calcium and phosphorus digestibility in broilers, Lelis et al. (2010) obtained better phosphorus digestibility coefficient and higher phosphorus retention, as well as lower phosphorus excretion and higher tibial phosphorus content; however, calcium digestibility coefficient and tibial ash content was not statistically different.

Live performance results are presented in Table 4. Although phytase supplementation numerically improved broiler performance when compared to the negative control diet, results were not statistically different among treatments $(p<0.05)$. Carcass quality parameters were not influenced by the treatments (Table 5).

Table 4 - Live performance of 1 - to 42 -d-old broilers fed the experimental diets.

\begin{tabular}{lcccccc}
\hline & \multicolumn{3}{c}{ Treatments* $^{*}$} & CV & SEM & $P$ \\
\hline & PC & NC & $\begin{array}{c}\text { NC }+ \\
\text { phytase }\end{array}$ & $\%$ & & \\
\hline Average weight, g & 3.224 & 3.145 & 3.176 & 2.58 & 165 & 0.632 \\
\hline Feed intake, g & 4.858 & 5.052 & 4.846 & 2.21 & 518 & 0.675 \\
\hline Weight gain, g & 3.176 & 3.096 & 3.126 & 2.65 & 165 & 0.631 \\
\hline $\begin{array}{l}\text { Feed conversion } \\
\text { ratio, g/g }\end{array}$ & 1.53 & 1.63 & 1.55 & 1.88 & 0.12 & 0.388 \\
\hline * PC - positive control; NC - negative control. $(\mathrm{p}<0.05)$ & & &
\end{tabular}

Table 5 - Carcass traits of broilers fed the experimental diets.

\begin{tabular}{|c|c|c|c|c|c|c|}
\hline & \multicolumn{3}{|c|}{ Treatments* } & CV & SEM & $P$ \\
\hline & PC & NC & $\mathrm{NC}+$ phytase & $\%$ & & \\
\hline Carcass, \% & 72.92 & 73.09 & 72.59 & 3.17 & 2.10 & 0.585 \\
\hline Breast, \% & 30.73 & 30.55 & 29.75 & 4.12 & 1.75 & 0.156 \\
\hline Leg, \% & 31.30 & 31.16 & 31.31 & 3.61 & 1.44 & 0.933 \\
\hline
\end{tabular}

* PC - positive control; NC - negative control. $(p<0.05)$

Broiler tibial calcium content was not influenced by the evaluated diets (Table 6). However, dietary phytase supplementation increased tibial ash content when compared with the negative control diet. Broilers fed the diet supplemented with phytase presented similar tibial phosphorus content compared with those fed the positive control diet and higher compared with those fed the negative control diet $(p<0.05)$. 
Table 6 - Ash, calcium, and phosphorus tibial contents of broilers fed the experimental diets.

\begin{tabular}{|c|c|c|c|c|c|c|}
\hline & \multicolumn{3}{|c|}{ Treatments* } & \multirow{2}{*}{$\frac{\text { CV }}{\%}$} & \multirow[t]{2}{*}{ SEM } & \multirow[t]{2}{*}{$p$} \\
\hline & PC & $\mathrm{NC}$ & $\begin{array}{c}\mathrm{NC}+ \\
\text { phytase }\end{array}$ & & & \\
\hline Ashes, \% & $53.59^{a}$ & $50.41^{c}$ & $52.39^{b}$ & 3.94 & 1.00 & $<0.001$ \\
\hline Calcium, \% & 20.72 & 19.90 & 20.02 & 5.18 & 1.17 & 0.333 \\
\hline Phosphorus, \% & $9.73^{a}$ & $9.04^{b}$ & $9.51^{\mathrm{a}}$ & 4.44 & 0.28 & $<0.001$ \\
\hline
\end{tabular}

* $\mathrm{PC}$ - positive control; NC - negative control. $(p<0.05)$

The obtained results are different from those found by Laurentiz et al. (2005), who observed that broilers fed diets containing phytase and reduced phosphorus levels did not present higher mineral deposition in the tibia, but that tibial ash and phosphorus contents were reduced when a diet containing reduced phosphorus levels was fed.

\section{CONCLUSIONS}

The supplementation of phytase to broiler diets increased dietary calcium and phosphorus digestibility, and consequently, improved bone quality.

\section{ACKNOWLEDGEMENTS}

The authors thank the companies Salus Comércio de Produtos de Saúde e Nutrição Animal Ltda and Beijing Smile Feed Sci \& Tech Co. Ltd. for funding this study.

\section{REFERENCES}

Bess F, Rosa AP, Krabbe EL, Souza TBS, Favero A. Efeito da adição de fitase sobre a percentagem de postura e densidade de ovos em matrizes de corte. Anais da Conferência Apinco 2006 de Ciência e Tecnologias Avícolas, 2006, Santos, São Paulo. Brasil. Campinas: FACTA; 2006. p.106.

Dari RL. A utilização de fitase na alimentação de aves. Anais da Conferência Apinco 2004 de Ciência e Tecnologias Avícolas; 2004; Santos, São Paulo. Brasil.Campinas: FACTA; 2004. v.1. p.127-143

Dourado LRB, Sakomura NK, Fukayama EH, Neme R, Aguilar CAL, Barbosa NAA. Efeito da suplementação da fitase na digestibilidade dos nutrientes em rações de frangos de corte. Revista Brasileira de Ciência Avícola. Premio Lamas 2006; Supl. 8:12.

Fukayama EH, Sakomura NK, Dourado LRB, Neme R, Fernandes JBK, Marcato SM. Efeito da suplementação de fitase sobre o desempenho e a digestibilidade dos nutrientes em frangos de corte. Revista Brasileira Zootecnia 2008;37(4):629-635.

Laurentiz AC, Junqueira OM, Marques RH, Artoni SMB, Costa R, Moreira LPC. Composição do fígado e da tíbia de frangos de corte alimentados com dietas contendo fitase e níveis reduzidos de fósforo. Revista Brasileira de Ciência Avícola. Premio Lamas 2005; Supl. 7:92.

Lelis GR, Albino LFT, Silva CR, Rostagno HS, Gomes PC, Borsatto CG. Suplementação dietética de fitase sobre o metabolismo de nutrientes de frangos de corte. Revista Brasileira Zootecnia 2010;39(8):17681773

Rostagno HS, Albino LFT, Donzele JL, Gomes PC, Oliveira RF, Lopes DC, Ferreira AS, Barreto SLT, Euclides RF. Tabelas brasileiras para aves e suínos: composição de alimentos e exigências nutricionais. $3^{\mathrm{a}} \mathrm{ed}$. Viçosa: UFV, DZO; 2011. 252 p.

Statistical Analysis System. SAS user's guide: statistics. Version 9.2. Cary; 2008 